\title{
A STRATEGIC COST-BENEFIT ANALYSIS OF ENERGY POLICIES: COMPARATIVE ANALYSIS
}

harry Davitian, Richard J. Goettle IV, Paul J. Groncki, Edward A. Hudson, Peter Kleeman, Joan LUKachinski

October 1979

\section{MASTER}

NATIONAL CENTER FOR ANALYSIS OF ENERGY SYSTEMS DEPARTMENT OF ENERGY AND ENVIRONMENT

- BROOKHAVEN NATIONAL LABORATORY UPTON, NEW YORK 11973 


\section{DISCLAIMER}

This report was prepared as an account of work sponsored by an agency of the United States Government. Neither the United States Government nor any agency Thereof, nor any of their employees, makes any warranty, express or implied, or assumes any legal liability or responsibility for the accuracy, completeness, or usefulness of any information, apparatus, product, or process disclosed, or represents that its use would not infringe privately owned rights. Reference herein to any specific commercial product, process, or service by trade name, trademark, manufacturer, or otherwise does not necessarily constitute or imply its endorsement, recommendation, or favoring by the United States Government or any agency thereof. The views and opinions of authors expressed herein do not necessarily state or reflect those of the United States Government or any agency thereof. 


\section{DISCLAIMER}

Portions of this document may be illegible in electronic image products. Images are produced from the best available original document. 


\title{
A STRATEGIC COST-BENEFIT ANALYSIS OF ENERGY POLICIES: COMPARATIVE ANALYSIS
}

\author{
Harry DaVItian \\ PAUL J. GRONCKI \\ Peter Kleeman \\ JOAN LUKACHINSKI \\ National Center for Analysis of Energy Systems \\ Brookhaven National Laboratory \\ RICHARD J. GOETTLE IV \\ EDWARD A. HUdSON \\ Dale W. Jorgenson Associates
}

October 1979

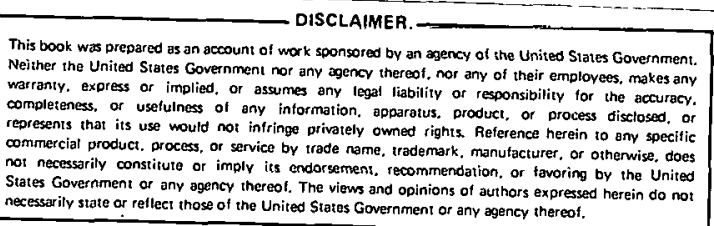

ECONOMIC ANALYSIS DIVISION

NATIONAL CENTER FOR ANALYSIS OF ENERGY SYSTEMS DEPARTMENT OF ENERGY AND ENVIRONMENT BROOKHAVEN NATIONAL LABORATORY. ASSOCIATED UNIVERSITIES, INC.

Prepared for the Office of Policy, Planning and Evaluation, Conservation and Solar Applications, U.S. Department of Energy under Contract No. DE-ACO2-76CH00O16 


\section{DISCLAIMER}

This book was prepared as an account of work sponsored by an agency of the United States Government. Neither the United States Government nor any agency thereof, nor any of their employees, makes any warranty, express or implied, or assumes any legal liability or responsibility for the accuracy, completeness, or usefulness of any information, apparatus. product, or process disclosed, or represents that its use would not infringe privately owned rights. Reference herein to any specific commercial product, procese, or service by trade name, trademarle; manufacturcr, or atherwize, does not necessarily constitute or imply its endorsement, recommendation, or favoring by the United States Government or any agency thercof. The vicws and opinions of authors expressed herein do not necessarily state or reflect those of the United States Government or any agency thereof.

Printed in the United States of America Available from

National Technical Information Service

U.S. Department of Commerce 5285 Port Royal Road Springfield, VA 22161

Price: Printed Copy $\$ 4.50$; Microfiche $\$ 3.00$ 


\section{ABSTRACT}

Current U.S. energy policy includes many programs directed toward restructuring the energy system in order to decrease U.S. dependence on foreign supplies and to increase our reliance on plentiful and environmentally benign energy forms. However, recent events have led to renewed. concern over the direction of current energy policy. This study describes three possible energy strategles and analyzes each in terms of its economic, environmental, and national security benefits and costs. Each strategy is represented by a specific policy. In the first strategy no additional programs or policies are inttiated beyond those currently in effect or announced. The second is directed toward reducing the growth in energy demand, i.e., energy conservation. The third promotes increased domestic supply through accelerated development of synthetic and unconventional fuels. The analysis focuses on the evaluation and comparison of these strategy alternatives with respect to their energy, economic, and environmental consequences. The results indicate that conservation can substantially reduce import dependence and slow the growth of energy demand, with only a small macroeconomic cost and with substantial environmental benefits; the synfuels policy reduces imports by a smaller amount, does not reduce the growth in energy demand, involves substantial environmental costs and slows the rate of economic growth. These relationships could be different if the energy savings per unit cost for conservation are less than anticipated, or if the costs of synthetic fuels can be significantly lowered. Given these uncertainties, both conservation and RD\&D support for synfuels should be included in future energy policy. However, between these policy alternatives, conservation appears to be the preferred strategy.

The results of this study are presented in three reports. The Overview presents a brief discussion of the motiviation for the study, the assumptions and methodologies employed, the results, and the policy implications. The Detalled Projections provides a more complete discussion of the input assumptions, methodology and results of the three strategies analyzed. The Comparative Analysis discusses the projections relative to each other, presents some sensitivity analyses that were performed, and provides a thorough discussion of the policy implications of the results.

\section{ACKNOWLEDGMENTS}

The authors wish to acknowledge their indebtedness to Hwei-Lin Hong, Dorothy Hatten, Elleen Kleiman, and Scott Rogers for their computational and other assistance in the preparation of this report. This report would not have been possible without the patience and typing skill of Margaret Gallite111, Susan Walsh, Vanessa Crump and June Martino. 
THIS PAGE

\section{WAS INTENTIONALLY LEFT BLANK}




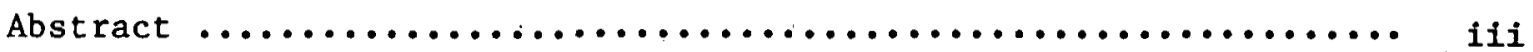

Acknowledgments $\ldots \ldots \ldots \ldots \ldots \ldots \ldots \ldots \ldots \ldots \ldots \ldots \ldots \ldots \ldots \ldots \ldots \ldots \ldots$

$1 \quad$ Introduction $\ldots \ldots \ldots \ldots \ldots \ldots \ldots \ldots \ldots \ldots \ldots \ldots \ldots \ldots \ldots \ldots \ldots$

2 A Comparison of the Consequences of Alternative

Energy Policies ............................... 2

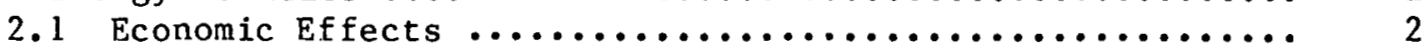

2.2 Energy System Effects $\ldots \ldots \ldots \ldots \ldots \ldots \ldots \ldots \ldots \ldots \ldots \ldots \ldots \ldots$. 11

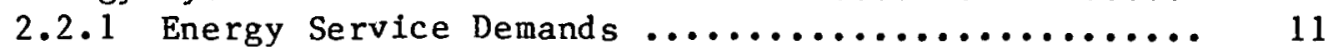

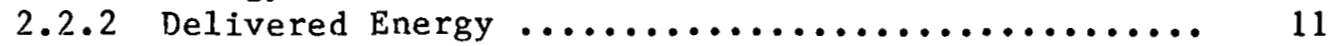

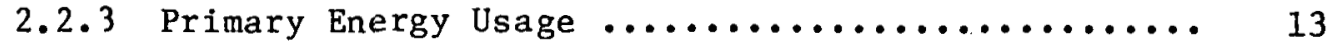

2.2.4 Energy System Efficiencies .................. 14

2.3 Environmental Implications $\ldots \ldots \ldots \ldots \ldots \ldots \ldots \ldots \ldots \ldots \ldots \ldots$

3 The Influence of Energy Policy Representations on

Economic Performance: A Sensitivity Analysis ........... 18

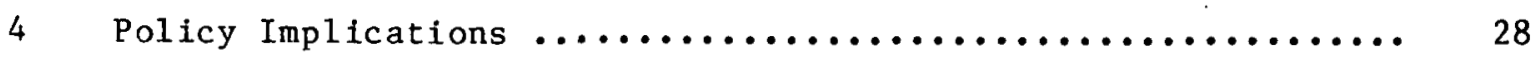

References.................................. 31

\section{TABLES}

1 Output and Productivity, Comparison of Cases $\ldots \ldots \ldots \ldots \ldots \ldots \ldots$

2 Energy and Economic Growth, Comparison of Cases ........... 5

3 Economic Output and Expenditure, Comparison of Cases ........ 5

4 The Discounted Net Benefits of Alternative Energy Policies:

GNP Effects ................................

5 The Discounted Net Benefits of Alternative Energy Policies:

Consumption Effects .......................... 7

6 Aggregate Final Demand Expenditures, Comparison of Cases ..... 8

7 Input-Output Coefficients for Aggregate Output, Comparison of Synfuels with Conservation Case ............

8 Input-Output Coefficients for Aggregate Output, Comparison of Reference with Conservation Case ...........

9 Input-Output Coefficients for Aggregate Output, Comparison of Reference with Synfuels Case 
10 The Level and Growth of Energy Service Demands,

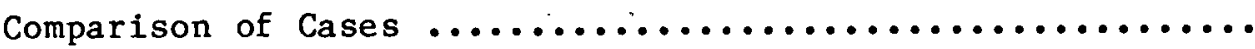

11 Delivered Energy Quantities by Fuel Type,

Comparison of Cases ........................... 12

12 Total Primary Energy Growth and Use,

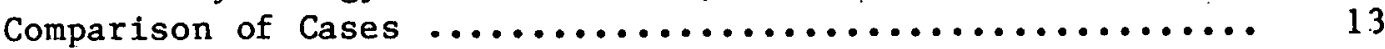

13 Primary Energy Usage, Comparison of Cases $\ldots \ldots \ldots \ldots \ldots \ldots \ldots \ldots$

14 Aggregate Energy Quantities and System Efficiencies, Comparison of Cases ........................... 16

15 Environmental Measures, Comparison of Cases ............. 17

16 Effects on Total Annual Policy Costs of Varying the Expenditure Growth Rates for the Constant Rate of

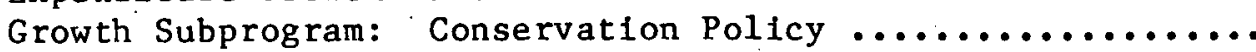

17 Effects on Total Annual Policy Costs for Varying the Time Intervals for the Trapezoidal Subprograms:

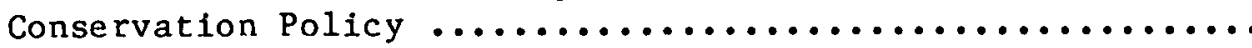

18 Effects on Total Annual Policy Costs of Varying the Expenditure Growth and Decline Rates for the Trapezoidal Subprograms: Conservation Pollcy ............

19 Effects on Total Annual Policy Costs of Combined Variations for the Trapezoidal Subprograms:

Conservation Policy

Effects on Total. Annual Policy Costs and Economic Performance of Combined Variations in the Annualization Schenes for Conservation Subprograms ........ 24

21 The Discounted Net Benefits of Conservation Policy .......... 24

22 Impacts on Economic Performance and Benefits of Varying the Mix of Energy Savings from Conservation,

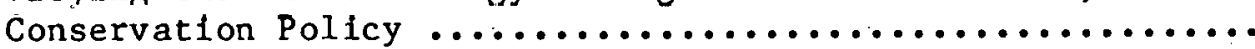

23 Impacts on Economic Performance and Benefits of the Effectiveness of the Conservation Policy .............

24 Impacts on Economic Performance and Benefits of Varying the Effectiveness of the Synfuels Policy 


\section{INTRODUCTION}

Recent developments affecting the price, availablitty, and safety of conventional energy supplies have provided anew both the motivation for a strategic review of domestic energy policy and the opportunity to define and clarify the future direction of that policy. By design and formulation, the Strategic Cost-Benefit Analysis of Energy Policles is intended to provide information to this process of evaluation. Specifically, the study defines three available directions for future energy policy and compares and evaluates each in terms of its energy, economic, and environmental consequences.

The results of this study are presented in three reports. The overview ${ }^{1}$ presents a brief discussion of the motiviation for the study, the assumptions and methodologies employed, the results, and the policy implications. The Detalled Projections ${ }^{2}$ provides a more complete discussion of the input assumptions, methodology and results of the three strategies analyzed. The Comparative Analysis discusses the projections re1ative to each other, presents the results of a series of sensitivity analyses, and provides a detailed discussion of the policy implications of the results.

Three major strategies are considered for possible use in developing future energy policy. The first introduces no new policies beyond those presently in effect. Operationally, this strategy presumes the implementation of only those policles currently enacted or currently announced and under direct control of the Executive Branch (including the oil import quota). The second strategy involves a redirection of policy toward demand reduction, i.e., energy conservation. The policy equivalent of this strategy is provided by a set of conservation initiatives, developed by the office of the Assistant Secretary of Conservation and Solar Applications (CSA), that are proposed for introduction beginning in FY 1981. The third strategic option is to promote increased domestic supply, primarily through an accelerated commercial development of the so-called synthetic and unconventional fuels. This policy direction is analyzed in terms of the program that was proposed by President Carter on July 15, 1979 .

The consequences of these policy alternatives are examined for the perlod 1980 , to 2000 using the combined Brookhaven National. Laboratory/ Dale W. Jorgenson Assoclates (BNL/DJA) energy-economy model system (TESOM-LITM). 3 The DJA economic model (LITM) depicts production and spending throughout the economy within a flexible interindustry framework. ${ }^{4}$ The model provides for substitutions in the final spending on the goods and services that comprise the Gross National Product. Further, it permits substitutions among the capital, labor, energy, and materials inputs into the production of these goods and services. The BNL component of the system (TESOM) is a technological model of energy extraction, conversion, and end use. 5 It represents the economic, technical, and environmental characteristics of the future substitution possibilities among new and conventional energy technologies and energy sources. The combined models give a comprehensive long-run representation of the nation's energy and economic systems, energy-economy interactions, and the environmental consequences of these. Using this integrated system, the method of analysis is, first, to project developments under the no new policy 
strategy and, then, to perform alternative projections corresponding to each of the more active policies. The three cases are then compared to provide an estimates of

- the relative merits of the strategies as measured by national energy security objectives;

- the costs imposed on (or, benefits realized by) the U.S. economy for each strategy;

- the environmental consequences arising from the energy system under each strategy.

The purpose of this report is to present the major findings of this comparison and to develop their implications for the future direction of national energy policy.

\section{A COMPARISON OF THE CONSEQUENCES OF ALTERNATIVE ENERGY POLICIES}

In this section, a comparative assessment of the effects of the conservation and synfuels policies is presented. The analysis centers on the overall effectiveness of these policies as compared to the reference projection (no new policy) and in the context of strategic energy, economic, and environmental national policy objectives.

\subsection{Economic Effects}

The introduction of policies to encourage curtailment of the growth in energy demand or to promote accelerated expansion of domestic energy supply has a significant effect on the growth and structire of the nation's economy. In general, the conservation pollcy is economically superior to the synfuels policy in achieving energy reductions consistent with national objectives. However, from the perspective of the reference projection, an economic cost results from the introduction of either of the more active policies.

Comparative final output and productivity measures for the policy alternatives are shown in Table 1. Through 1990, real GNP is lower than that for the reference projection under both the conservation and the synfuels polictes. In the case of conservation, the 2.2 billion $\$(1972)$ reduction tn economic activity is the net consequence of equilibrated supply and demand responses to changes $I n$ spending and production patterns throughout the economy. The conservation programs, to be successful, require significant commitments of the capital and labor resources avallable within the economy. These additional claims are measured against the release of resources permitted by conservation, 1.e., reductions in the required levels of energy pruduction. To the extent that resource claims exceed releases, additional resources must be diverted from other productive uses because of their strictly limited availabilities. This reallocation is not without cost in terms of economic efficiency. Thus, in 1990, the small net diversion of avallable resources to conservation activities leads to a 0.1 percent decline in real GNP.

For the synfuels policy, the causes of the 12.4 billion $\$(1972)$ reduction in the 1990 level of real GNP are similar. Expansion of the domestic supply by means of synthetic and unconventional fuels requires 
Table 1

Output and Productivity, Comparison of Cases

\begin{tabular}{lrrr}
\hline & Reference & Conservation & Synfuels \\
\hline 1990 & & & \\
Real GNP, $10^{9} \$(1972)$ & 1901.3 & 1899.1 & 1888.9 \\
Real GNP per capita, $10^{3} \$(1972)$ & 7.808 & 7.799 & 7.757 \\
Gross labor productivity/worker, & & & \\
$10^{3} \$(1972)$ & 16.885 & 16.881 & 16.805 \\
2000 & & & \\
Real GNP & 2469.3 & 2473.7 & 2413.3 \\
Real GNP per capita & 9.483 & 9.500 & 9.268 \\
Gross labor productivity & 19.834 & 19.869 & 19.462 \\
Average annual growth rates, percent & & & \\
1980-1990 & & & \\
Real GNP & 2.98 & 2.97 & 2.92 \\
Real GNP per capita & 2.04 & 2.03 & 1.98 \\
Gross labor productivity & 1.54 & 1.54 & \\
1990-2000 & & & 2.49 \\
Real GNP & 2.65 & 2.68 & 1.80 \\
Real GNP per capita & 1.96 & 1.99 & 1.48 \\
Gross labor productivity & 1.62 & 1.64 & \\
\hline
\end{tabular}

the deployment of technologies that provide energy at a cost not yet competitive with that of energy from the conventional sources they displace. As there is a substantial drain on the resources available for other productive activities, the synfuels policy imposes a significant cost in terms of income and production foregone. This cost is greater than that caused by the conservation policy and, consequently, has a more permanent effect on future economic performance.

By the year 2000 , the synfuels policy results in additional pena1ties to economic growth. Even though the synfuels technologies become increasingly more competitive with conventional energy supplies, their accelerated commerclal application has a cumulative, adverse impact of sufficient magnitude to preclude economic recovery. In 2000 , the level of real GNP under the synfuels policy, is 2.3 percent or 56.0 billion $\$(1972)$ below that in the reference projection.

However, the conservation policy provides net economic benefits in this period. Here, the total resource claims of the conservation activities are more than equally compensated by the benefits of energy displaceututs and reduced energy production. The gains in economic efficiency from providing lower cost energy through conservation permit an increase in net outpur. That is, real GNP is increased to 2473.7 billion $\$(1972), 0.2$ percent above the reference case level. 
With annual rates of labor force expansion approximately equal for the three cases, the macroeconomic impacts of the alternative policies translate directly into productivity effects. For the period 1980 to 1990 , the rates of advance in gross labor productivity for the reference and conservation projections are almost identical. Moreover, they lie above the rate determined for the economy under the synfuels policy. To the end of the century, the productivity advance associated with conservation dominates those of the other cases.

The implications for the aggregate economic efficiency of energy use under these policies are of sufficient clarity to warrant little elaboration. The energy-GNP ratio and its components are shown in Table 2. Conservation provides a dramatic acceleration of the gains realized for this measure over the projection horizon. Conversely, the synfuels policy slows the rate of 1mpruvement rclative to the reference case. For conservation the annual rate of decline in the energy-GNP ratio is 2.4 percent for the period 1980 to 1990 and 2.5 percent tn the year 2000 . These are slightly more and less than double the rates of improvement observed for the synfuels and reference projections, respectively.

The changes in the pattern of economic growth are illustrated further by the division of total final output into consumption and investment purchases. These are presented in Table 3. In 1990, consumption absorbs 89.0 percent of the decline in real GNP under the synfuels policy. Investment accounts for the remaining 11.0 percent of the GNP decline. In 2000 under this policy, the fractions of the total decline in real economic activity attributable to consumption and investment are 85.0 and 15.0 percent, respectively. In these situations, the losses in overall economic efficiency due to the synfuels policy reduce the net output and corresponding incomes that are achievable within the economy. In the static sense, investment, as a component of aggregate demand, is reduced because of the reduction in real income and the associated decline in saving. In each year that investment falls, the re is a corresponding reduction in the available capital stock. Over time, the olower growth of capital stock slows the growth of the produclive potential of the economy and thus reduces the incentive for saving aud investment, i.e., the prospective rate of return to capital. In the earlier years, the expenditure reductions are concentrated on consumption rather than investment, since the price impacts of the synfuels policy primarily affect consumption and as there is a partially offsetting boost to investment due to the capital requirements of these technologies. Later, however, the situation is altered. The proportionate decline in investment increases under the dynamic influences of the saving and rate of return effects. The consequent slowing of capital growth accentuates the rcductions in rea1. GNP due to the efficiency effects.

For the conservation case, there is again evidence that the burden of economic losses falls relatively more heavily on consumption. Under the conservation policy in 1990, consumption absorbs 95.0 percent of the decline in real GNP with investment accounting for the remainder. How ever, in the nineties, the economy realizes efficiency gains from this policy, so that economic growth over the final decade of the century is 
Table 2

Energy and Economic Growth, Comparison of Cases

\begin{tabular}{llccc}
\hline Year & \multicolumn{1}{c}{ Policy } & $\begin{array}{c}\text { Real GNP } \\
\text { (billions of } \\
1972 \text { dollars) }\end{array}$ & $\begin{array}{c}\text { Primary energy } \\
\text { (quadrillion } \\
\text { Btu) }\end{array}$ & $\begin{array}{c}\text { Energy-GNP ratio } \\
\text { (thousand Btu per } \\
1972 \text { dollars) }\end{array}$ \\
\hline 1990 & Reference & 1901.3 & 96.9 & 51.0 \\
& Conservation & 1899.1 & 86.6 & 45.6 \\
& Synfuels & 1888.9 & 98.9 & 52.4 \\
& Reference & 2469.3 & 109.5 & 44.3 \\
& Conservation & 2473.7 & 87.2 & 35.3 \\
& Synfuels & 2413.3 & 113.6 & 47.1 \\
\hline
\end{tabular}

Table 3

Economic Output and Expenditure, Comparison of Cases

\begin{tabular}{|c|c|c|c|c|}
\hline & & Reference & Conservation & Synfuels \\
\hline \multicolumn{5}{|c|}{$\begin{array}{l}\text { Real GNP components, } \\
\text { billions of } 1972 \text { dollars }\end{array}$} \\
\hline 1990 & $\begin{array}{l}\text { Consumption } \\
\text { Inves tment } \\
\text { GNP }\end{array}$ & $\begin{array}{r}1235.2 \\
283.7 \\
1901.3\end{array}$ & $\begin{array}{r}1233.1 \\
283.6 \\
1899.1\end{array}$ & $\begin{array}{r}1224,2 \\
282.3 \\
1888.9\end{array}$ \\
\hline 2000 & $\begin{array}{l}\text { Consumption } \\
\text { Investment } \\
\text { GNP }\end{array}$ & $\begin{array}{r}1605.6 \\
368.0 \\
2469.3\end{array}$ & $\begin{array}{r}1607.7 \\
370.3 \\
2473.7\end{array}$ & $\begin{array}{r}1557.8 \\
359.8 \\
2413.3\end{array}$ \\
\hline $\begin{array}{l}\text { Compo } \\
1990\end{array}$ & $\begin{array}{l}\text { on of real GN } \\
\text { Consumption } \\
\text { Investment } \\
\text { GNP }\end{array}$ & $\begin{array}{r}65.0 \\
14.9 \\
100.0\end{array}$ & $\begin{array}{r}64.9 \\
14.9 \\
100.0\end{array}$ & $\begin{array}{r}64.8 \\
14.9 \\
100.0\end{array}$ \\
\hline 2000 & $\begin{array}{l}\text { Consumption } \\
\text { Investment } \\
\text { GNP }\end{array}$ & $\begin{array}{r}65.0 \\
14.9 \\
100.0\end{array}$ & $\begin{array}{r}65.0 \\
15.0 \\
100.0\end{array}$ & $\begin{array}{r}64.6 \\
14.9 \\
100.0\end{array}$ \\
\hline
\end{tabular}


slightly higher than that in the reference case. The recovery, relative to 1990 and the reference projection, results from the excess of direct policy benefits over the policy costs. This excess permits the increase in net output and, since capital formation is one of the main stimulants promoting the increase, investment necessarily grows in a manner consistent with the expansion in real GNP.

In comparing macroeconomic performance among the alternative projections, two of the three possible policy comparisons are straightforward. Over the entire projection horizon, real GNP is higher under the conservation and reference case policles than it is with the implementation of the synfuels programs. The synfuels policy clearly imposes an economic cost in terms of income and production foregone. Not so obvious, however, is whether the conservation policy shows overall net economic costs or benefits lu cumparison to the reference projertion. Therefore, it becomes useful to develop a measure that represents the policy costs or benefies throughoul the entire period 1980 to 2000 .

For any two policy cases, a common measure for such representations is provided by the present value of the differences between indicators of economic performance. Computationally, this value accumulates annual differences in economic variables where these are discounted to a nearterm reference period through weights that reflect a social rate of interest. Thus, at selected discount rates, the present value formulation permits the determination of overall net policy benefits or costs.

Applying the present value formulation to differences in real GNP yields the results shown in Table 4. These figures support the conclusion that the policies underlying the reference and conservation cases are more beneficial economically than those for the synfuels projection. However, at reasonable social rates of discount, the conservation policy also Involves an economic cost when viewed from the perspective of the reference projection. Only at extremely low discount rates does the conservation policy produce net economic benefits.

Table 4

The Discounted Net Benefits of Alternative Energy Policies: GNP Effects* (Billions of 1972 dollars)

\begin{tabular}{lrrr}
\hline & \multicolumn{3}{c}{ Soclal discount rate } \\
\cline { 2 - 4 } \multicolumn{1}{c}{ Cases } & \multicolumn{1}{c}{$0 \%$} & $5 \%$ & $10 \%$ \\
\hline Reference vs conservation & 0.4 & -3.7 & -4.3 \\
Ruference va synfucle & -410.0 & -200.7 & -106.7 \\
Synfuels vs conservation & 410.4 & 197.0 & 102.4 \\
\hline
\end{tabular}

*Determined as changes between cases in the present value of real GNP. 
The national income accounts give another basis for measuring economic performance that is, perhaps, a better indicator of economic welfare than is real GNP. This measure is the sum of real personal consumption and government purchases or real private and public consumption. This indicator reflects the volume of goods and services that society extracts from the economy for its current use. As the benefit from investment is future consumption and since this is included in the measure of economic performance, investment is excluded. Its purpose is to provide output in the future, rather than to sustain current use. On the other hand, real personal consumption is a direct use of output for the satisfaction of individual preferences. Government purchases are a simflar use of output except that preferences are revealed through the political process and are satisfied collectively.

The information in Table 5 was determined by applying the present value formulation to the differences in real public and private consumption between the policy cases. The results here are more decisive; neither of the more active policies is costless when compared to the reference projection. Under this criterion alone, the conservation policy again is preferred to the synfuels programs, but the policies of the reference projection are preferable to both.

The policies also differ in their impact on the sectoral patterns of final spending and, hence, the output mix of the economy. Table 6 summarizes the sectoral composition of aggregate demand expenditures for the policy alternatives. The most noticeable feature of this is energy's share of final spending. Conservation both promotes and permits traditional energy expenditures to be redirected toward spending on nonenergy goods and services. These are concentrated, for the most part, in additional purchases from the manufacturing and trade and service sectors. Thus, relative to the structures of final demand for the other projections, energy's share is the smallest and the shares of manufacturing and trade and services are the largest under the conservation policy. The

Table 5

The Discounted Net Benefits of Alternative Energy Policies: Consumption Effects*

(Billions of 1972 dollars)

\begin{tabular}{lrrr}
\hline & \multicolumn{3}{c}{ Social discount rate } \\
\cline { 2 - 4 } \multicolumn{1}{c}{ Cases } & $0 \%$ & $5 \%$ & $10 \%$ \\
\hline Reference vs conservation & -10.3 & -8.2 & -6.2 \\
Reference vs synfuels & -353.7 & -173.6 & -92.5 \\
Synfuels vs conservation & 343.4 & 165.4 & 86.3 \\
\hline * Determined as changes between cases in the present value of real & & \\
consumption plus government expenditures. & & & \\
\hline
\end{tabular}


Table 6

Aggregate Final Demand Expenditures, Comparison of Cases

\begin{tabular}{|c|c|c|c|c|}
\hline & & Reference & Conservation & Synfuels \\
\hline $\begin{array}{l}\text { Purch } \\
1990\end{array}$ & $\begin{array}{l}\text { s, billions of } 1972 \text { doll } \\
\text { Agriculture, nonfuel } \\
\text { mining, construction } \\
\text { Manufacturing } \\
\text { Transportation } \\
\text { Services } \\
\text { Energy }\end{array}$ & $\begin{array}{r}173.0 \\
522.0 \\
66.1 \\
1157.2 \\
77.8\end{array}$ & $\begin{array}{r}172.5 \\
522.4 \\
66.0 \\
1167.0 \\
59.6\end{array}$ & $\begin{array}{r}171.6 \\
517.0 \\
65.0 \\
1146.8 \\
83.0\end{array}$ \\
\hline 2000 & $\begin{array}{l}\text { Agriculture, nonfuel } \\
\quad \text { mining, construction } \\
\text { Manufacturing } \\
\text { Transportation } \\
\text { Services } \\
\text { Energy }\end{array}$ & $\begin{array}{r}213.6 \\
704.1 \\
102.1 \\
1540.7 \\
81.9\end{array}$ & $\begin{array}{r}212.6 \\
706.4 \\
99.6 \\
1559.0 \\
63.0\end{array}$ & $\begin{array}{r}208.8 \\
687.8 \\
99.6 \\
1509.7 \\
83.0\end{array}$ \\
\hline $\begin{array}{l}\text { Compo } \\
1990\end{array}$ & $\begin{array}{l}\text { ion of purchases, percen } \\
\text { Agriculture, nonfuel } \\
\text { mining, construction } \\
\text { Manufacturing } \\
\text { Transportation } \\
\text { Services. } \\
\text { Energy }\end{array}$ & $\begin{array}{r}8.67 \\
26.15 \\
3.31 \\
57.97 \\
3.90\end{array}$ & $\begin{array}{r}8.68 \\
26.28 \\
3.32 \\
58.72 \\
\quad 3.00\end{array}$ & $\begin{array}{r}8.65 \\
26.07 \\
3.28 \\
57.82 \\
4.18\end{array}$ \\
\hline 2000 & $\begin{array}{l}\text { Agriculture, nonfuel } \\
\quad \text { mining, construction } \\
\text { Manufacturing } \\
\text { Transportation } \\
\text { Services } \\
\text { Energy }\end{array}$ & $\begin{array}{r}8.08 \\
26.65 \\
3.86 \\
58.31 \\
3.10\end{array}$ & $\begin{array}{r}8.05 \\
26.7 .5 \\
3.77 \\
59.04 \\
2.39\end{array}$ & $\begin{array}{r}8.07 \\
26.57 \\
3.85 \\
58.31 \\
3.21\end{array}$ \\
\hline
\end{tabular}

synfuels policy, however, substitutes energy from high cost technologies for that available from lower cost, conventional sources. The absolute and the relative importances of energy in final demand spending are, therefore, larger for this projection. The imposition of more expensive energy requires a redirection of expenditures on nonenergy goods and acrvices toward energy purchases; this is diametrir to the impact of the conservation policy.

The mix of illputs into production provides the final basis for compariug the thrce cases. The input-output coefficients for capital, labor, energy, and intermediate materials are presented and compared in Tables 7 through 9. In all cases, the general trend is for the economy to grow continually more capital intensive and less intensive in the use of 1 abor and energy. However, the magnitudes of the changes differ significantly, depending on the policy being considered. According to these 
Table 7

Input-Output Coefficients for Aggregate Output, Comparison of Synfuels with Conservation Cases

\begin{tabular}{|c|c|c|c|c|}
\hline Year & Factor & Synfuels case & Conservation case & $\%$ change \\
\hline 1990 & $\begin{array}{l}\text { Capital } \\
\text { Labor } \\
\text { Energy } \\
\text { Materials }\end{array}$ & $\begin{array}{l}.1793 \\
.2080 \\
.0298 \\
.5829\end{array}$ & $\begin{array}{l}.1794 \\
.2072 \\
.0272 \\
.5862\end{array}$ & $\begin{array}{r}0.06 \\
-0.38 \\
-8.72 \\
0.57\end{array}$ \\
\hline $\begin{array}{l}\text { Percent change } \\
(1980-1990)\end{array}$ & $\begin{array}{l}\text { Capital } \\
\text { Labor } \\
\text { Energy } \\
\text { Materials }\end{array}$ & $\begin{array}{l}19.14 \\
-8.49 \\
-5.10 \\
-1.34\end{array}$ & $\begin{array}{r}19.20 \\
-8.84 \\
-13.38 \\
-0.78\end{array}$ & \\
\hline 2000 & $\begin{array}{l}\text { Capital } \\
\text { Labor } \\
\text { Energy } \\
\text { Materials }\end{array}$ & $\begin{array}{l}.2052 \\
.1845 \\
.0283 \\
.5819\end{array}$ & $\begin{array}{l}.2041 \\
.1815 \\
.0267 \\
.5876\end{array}$ & $\begin{array}{r}-0.54 \\
-1.63 \\
-5.65 \\
0.98\end{array}$ \\
\hline $\begin{array}{l}\text { Percent change } \\
(1990-2000)\end{array}$ & $\begin{array}{l}\text { Capital } \\
\text { Labor } \\
\text { Energy } \\
\text { Materials }\end{array}$ & $\begin{array}{r}14.45 \\
-11.30 \\
-5.03 \\
-0.17\end{array}$ & $\begin{array}{r}13.77 \\
-12.40 \\
-1.84 \\
0.24\end{array}$ & . \\
\hline
\end{tabular}

Table 8

Input-Output Coefficients for Aggregate Output, Comparison of Reference with Conservation Case

\begin{tabular}{llrrr}
\hline \multicolumn{1}{c}{ Year } & Factor & Reference case Conservation case & \% change \\
\hline 1990 & Capital & .1789 & .1794 & 0.28 \\
& Labor & .2077 & .2072 & -0.24 \\
& Energy & .0289 & .0272 & -5.88 \\
& Materials & .5844 & .5867 & 0.31 \\
Percent change Capital & 18.87 & 19.20 & \\
$(1980-1990)$ & Labor & -8.62 & -8.84 & \\
& Energy & -7.96 & -13.38 & -0.15 \\
2000 & Materials & -1.08 & -0.78 & -0.77 \\
& Capital & .2044 & .2041 & -4.30 \\
& Labor & .1829 & .1815 & 0.48 \\
Energy & .0279 & .0267 & \\
Percent change & Capital & 14.25 & .5876 & \\
& Labor & -11.94 & 13.77 & \\
& Energy & -3.46 & -12.40 & -1.84 \\
\hline
\end{tabular}




\begin{tabular}{|c|c|c|c|c|}
\hline \multicolumn{5}{|c|}{$\begin{array}{c}\text { Table } 9 \\
\text { Input-Output Coefficients for Aggregate Output, } \\
\text { Comparison of Reference with Synfuels Case }\end{array}$} \\
\hline Year & Factor & Reference case & Synfuels case & $\%$ change \\
\hline 1990 & $\begin{array}{l}\text { Capital } \\
\text { Labor } \\
\text { Energy } \\
\text { Materials }\end{array}$ & $\begin{array}{l}.1789 \\
.2077 \\
.0289 \\
.5844\end{array}$ & $\begin{array}{l}.1793 \\
.2080 \\
.0298 \\
.5829\end{array}$ & $\begin{array}{r}0.22 \\
0.14 \\
3.11 \\
-0.26\end{array}$ \\
\hline $\begin{array}{l}\text { Percent change } \\
(1980-1990)\end{array}$ & $\begin{array}{l}\text { Capital } \\
\text { Labor } \\
\text { Energy } \\
\text { Materials }\end{array}$ & $\begin{array}{l}18.87 \\
-8.62 \\
-7.96 \\
-1.08\end{array}$ & $\begin{array}{l}19.14 \\
-8.49 \\
-5.10 \\
-1.34\end{array}$ & \\
\hline 2000 & $\begin{array}{l}\text { Capital } \\
\text { Labor } \\
\text { Energy } \\
\text { Materials }\end{array}$ & $\begin{array}{l}.2044 \\
.1829 \\
.0279 \\
.5848\end{array}$ & $\begin{array}{l}.2052 \\
.1845 \\
.0283 \\
.5819\end{array}$ & $\begin{array}{r}0.39 \\
0.87 \\
1.43 \\
-0.50\end{array}$ \\
\hline $\begin{array}{l}\text { Percent change } \\
(1990-2000)\end{array}$ & $\begin{array}{l}\text { Capital } \\
\text { Labor } \\
\text { Energy } \\
\text { Materials }\end{array}$ & $\begin{array}{r}14.25 \\
-11.94 \\
-3.46 \\
0.07\end{array}$ & $\begin{array}{r}14.45 \\
-11.30 \\
-5.03 \\
-0.17\end{array}$ & \\
\hline
\end{tabular}

results, the common perception that conservation is relatively labor intensive is contradicted. By the end of the century, the conservation case is the least labor intensive, whereas, it is the synfuels policy that leads to the greatest labor intensity of aggregate output. Also, the rate of increase in the amount of capital per worker is largest in the conservation case, followed next by the reference projection. Since this is an important factor contributing to the advance of gross labor productivity, it follows that the greatest benefits in this area arise from the conservation policy. The synfuels policy, given this measure, is the least favorable to the rate of advance of gross labor productiv1ty. Finally, the rate of improvement in the energy efficiency of capital is largest for the conservation case and smallest for the synfuels pol1cy.

These influences of the policles on the input structure of the economy result from several considerations. Flrst, the policles requitre a withdrawal of productive resources from other activities within the economy. Simultaneously, they promote the substitution of new energy productlon cechnlyues so that rusources originally dedicated to producing conventional supplies are released. As indicated, the net withdrawals under the synfuels policy are substantially larger than those assoctated with the conservation policy. Finally, the new levels and structures of final spending under the policies are consistent only with reconfigured input patterns. With equilibrium a requirement in each factor market, these changes influence the relative price structure and, so, further affect 
input decisions. The interactions, however, continue from these adjustments, insofar as the pattern of input choices has an impact on macroeconomic performance.

The reciprocals of the input-output coefficients, 1.e., total output per unit of input, represent measures of average total productivity. Over the entire projection horizon, the productivities of labor and energy rise the most in the conservation case and the least in the synfuels case. Also, the conservation policy causes the slowest rate of decline in capital productivity, while the synfuels policy imposes the largest decrease. These differences in factor productivities contribute materially to the macroeconomic impacts that result from the introduction of these policies.

For the alternative energy policies, the principal comparative conclusions regarding the growth and structure of the U.S. economy are summarized as follows:

- The policies have a significant effect on the output and input structures of the economy, with energy changes being both the motivating force and the dominant impact.

- Positive economic growth at steadily declining rates continues under either the synfuels or the conservation policies.

- Both policies, when compared to the reference projection, are seen to impose an economic cost in terms of income and production foregone. However, conservation's impact on macroeconomic performance is neither large nor permanent and is significantly less than that imposed by the synfuels policy.

- Over the long run, the conservation pollcy has a favorable effect on both gross labor and average total factor productivities, whereas the reverse is true for the synfuels policy.

\subsection{Energy System Effects}

2.2.1 Energy Service Demands. The level and growth of energy service demands for the three policies are presented in Table 10. The energy service demand levels for the conservation and synfuels policies change directly with the level of economic activity from the reference projection. The slight decline in economic activity from the reference case to the conservation policy in 1990 results in no significant change in energy service demands. However, hy 200 , as economic growth uudei the enhanced conservation policy increases relative to the no new policy case, the demand for energy services increases. The synthetic fuels policy results in lower energy service demands in both 1990 and 2000 relative to the reference projection as economic activity is reduced over this period from the reference levels.

2.2.2 Delivered Energy. The levels and types of delivered energy forms which fulfill these energy service demands change significantly across the alternative policy specifications. Total delivered energy in the conservation case is 10 and 22 percent lower in 1990 and 2000, respectively, than the delivered fuels under the continuation of current 


\begin{tabular}{lccc}
\hline The Level and Growth of Energy Service & Demands, Comparison of Cases \\
\hline & $\begin{array}{c}\text { Reference } \\
\text { case }\end{array}$ & $\begin{array}{c}\text { Conservation } \\
\text { case }\end{array}$ & $\begin{array}{c}\text { Synfue1s } \\
\text { case }\end{array}$ \\
\hline Energy service levels, & & & \\
$\quad$ quadrillion Btu & 32.9 & 32.9 & 32.9 \\
1980 & 43.4 & 43.4 & 43.3 \\
1990 & 53.9 & 54.4 & 53.2 \\
2000 & & & \\
Energy service/growth rates, \%/yr & 2.8 & 2.8 & 2.8 \\
$1.980-1990$ & 2.2 & 2.3 & 2.1 \\
$1990-2000$ & & & \\
\hline
\end{tabular}

policy or under the enhanced synfuels policy. This is due to the increased efficlency of end-use energy utilizing devices made avallable by the conservation polley. Total delivered energy dues not change significantly under the synfuels policy (relative to the reference case) as the end-use demands are satisfied less efficiently and do not lead to as rapid a turnover of less efficlent energy utilizing end-use devices. Table 11 presents the delivered fuel $\mathrm{mix}$ for the alternative policies.

\begin{tabular}{|c|c|c|c|c|}
\hline & \multicolumn{2}{|c|}{$\begin{array}{c}\text { Table } 11 \\
\text { Delivered Energy Quantities by Fuel Type, } \\
\text { (Quadrillion Btu) }\end{array}$} & \multicolumn{2}{|c|}{ Comparison of Cases } \\
\hline : & & $\begin{array}{l}\text { Reference } \\
\text { case }\end{array}$ & $\begin{array}{c}\text { Conservation } \\
\text { case }\end{array}$ & $\begin{array}{l}\text { Synfuels } \\
\text { case }\end{array}$ \\
\hline 1990 & $\begin{array}{l}\text { Coal, coke, wod } \\
\text { 011, methanol } \\
\text { Gas, lo-Btu gas } \\
\text { Electricity } \\
\text { Direct solar, geothermal, } \\
\text { waste heat } \\
\text { Total* }\end{array}$ & $\begin{array}{r}11 \\
26 \\
1.8 \\
11 \\
\\
1 \\
68\end{array}$ & $\begin{array}{r}11 \\
22 \\
16 \\
11 \\
1 \\
61\end{array}$ & $\begin{array}{r}11 \\
26 \\
18 \\
11 \\
i \\
1 \\
68\end{array}$ \\
\hline 2000 & $\begin{array}{l}\text { Coal, coke, wood } \\
\text { O11, methanol } \\
\text { Gas, lo-Btu gas } \\
\text { Electriclty } \\
\text { Direct solar, geothermal, } \\
\text { waste heat } \\
\text { Total* }\end{array}$ & $\begin{array}{r}12 \\
26 \\
18 \\
15 \\
\\
6 \\
76\end{array}$ & $\begin{array}{r}10 \\
16 \\
13 \\
14 \\
\\
5 \\
59\end{array}$ & $\begin{array}{r}12 \\
25 \\
20 \\
14 \\
5 \\
76\end{array}$ \\
\hline
\end{tabular}

*Total may not add because of rounding. 
In 1990, the conservation policy results in significant reductions in oil and gas usage as the conservation programs have their greatest effects on the use of these fuels. By 2000, the major savings are still oil and gas fuels, but all fuel types experience reduced usage as the conservation programs take effect across a broader spectrum of activities.

The synfuels policy has no effect on the use of delivered fuel forms relative to the reference case in 1990 because of the slowing of the turnover of the energy-utilizing capital stock (specifically of liquids-utilizing types), as well as slower economic growth. These trends become more evident in 2000. The constancy of delivered energy use relative to the reference case (in conjunction with the slowing of economic growth) results in only slight shifts in the mix of delivered energy forms. Liquids use declines only slightly as synthetic liquids avallability is partially outweighed by the decrease in transportation requirements resulting from less economic activity. Gaseous fuels substitute somewhat for the relatively more expensive conventional oil for process heat and coal-fired electric generation.

2.2.3 Primary Energy Usage. Table 12 presents a comparison of total primary energy usage and its growth rate for the reference, conservation, and synfuels cases. Growth in total primary energy consumption is slowed significantly by the conservation policy over the 1980-1990 period. Primary energy use grows at almost one-third the rate of the

Table 12

Total Primary Energy Growth and Use, Comparison of Cases

\begin{tabular}{lccc}
\hline & $\begin{array}{c}\text { Reference } \\
\text { case }\end{array}$ & $\begin{array}{c}\text { Conservation } \\
\text { case }\end{array}$ & $\begin{array}{c}\text { Synfuels } \\
\text { case }\end{array}$ \\
\hline $\begin{array}{l}\text { Quantities, quads } \\
1980\end{array}$ & 82.0 & & \\
1990 & 96.9 & 82.0 & 82.0 \\
2000 & 109.4 & 86.6 & 98.9 \\
Average annua1 growth rates, \%/yr & & 87.0 & 113.6 \\
$\begin{array}{l}1980-1990 \\
1990-2000\end{array}$ & 1.68 & & \\
\hline
\end{tabular}

reference case and at about 30 percent of the synfuels growth rate. After 1990, the growth in primary energy use is essentially halted by the conservation policy. Some of the conservation programs analyzed actually supplied a fuel (Alternative Fuels Utilization) which was not captured as a primary energy form in TESOM, but was included in the conservation component of delivered energy. The synfuels policy contributes to an energy future characterized by the fastest growth in energy use of all of the policies examined. 
The primary energy trends of the conservation policy results from the increasingly energy efficient capital stocks as evidenced by the lower delivered energy requirements (relative to the reference case) discussed above. The synfuels case relies increasingly on the relatively inefficient coal-to-synthetic fuel conversion technologies, thus requiring, in 2000, 4 percent more primary energy for the same level of delivered energy as in the reference case.

The mix of fuels making up primary energy use varies across the policies in several significant ways (Table 13). In 1990, the conservation policy requires about 37 percent less imported oil than the reference projection and no imported natural gas. Lower gas, uranium, and geothermal usage reflects the small decreases in electricity consumption.

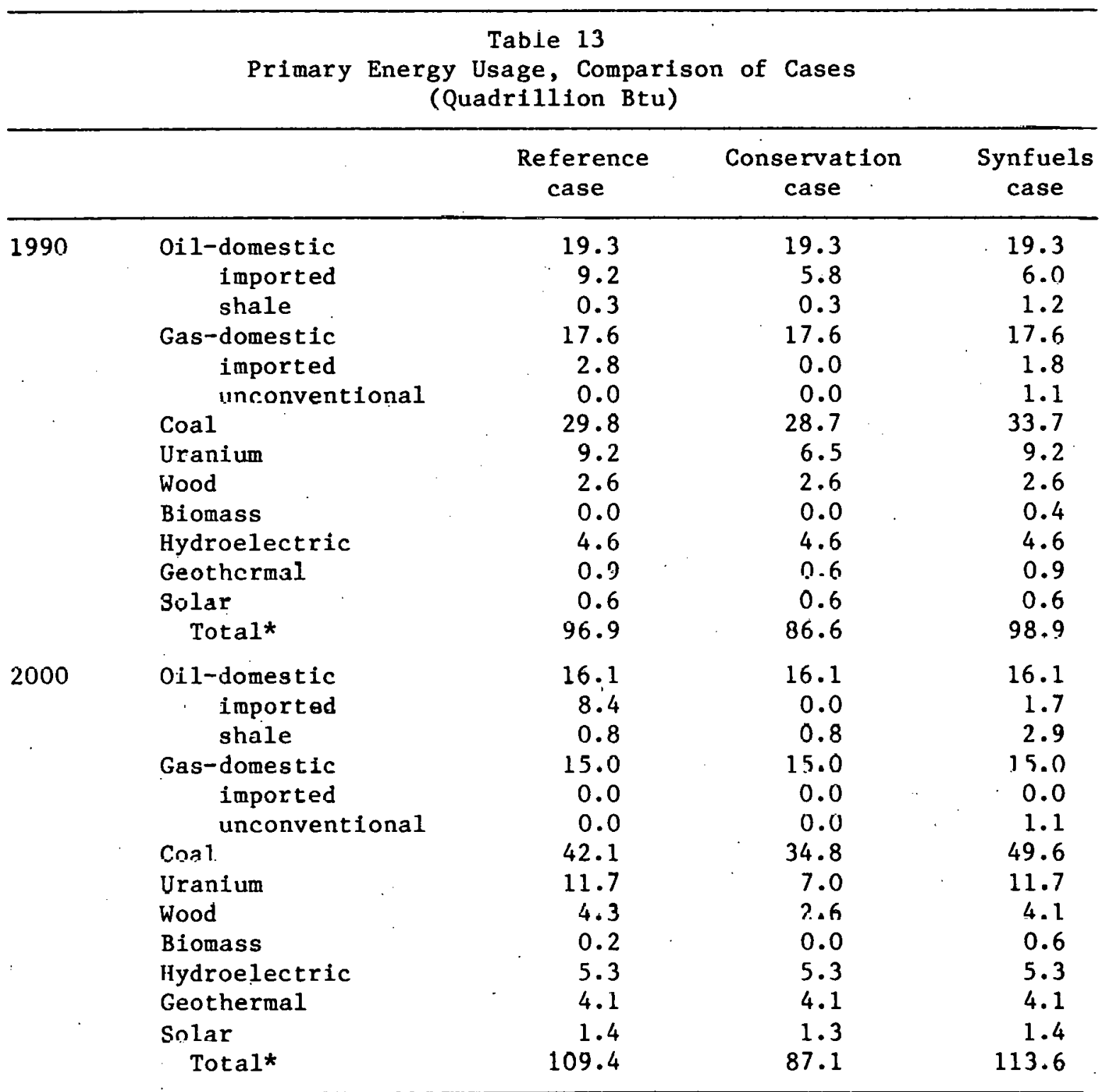

*Totals may not add because of rounding. 
By 2000, conservation reduces oll and gas imports to zero and effects significant reductions in coal, wood, biomass, and uranium usage. The synthetic fuels policy reduces oil imports by only 35 percent and gas imports by 36 percent in 1990. Shale oil production increases fourfold and unconventional gas usage of more than 1 quad occurs (specified by assumption). Thirteen percent more coal is consumed in the synfuels case compared to the reference case as a result of the supply enhancement program. No reductions in any primary energy type other than imported oil and gas from the reference case occur in 1990. By 2000, the synfuels policy requires the continuation of oil imports at about 20 percent. of the reference case level, in addition to 360 percent more shale oil, a quad of unconventional gas, 360 percent more biomass, and 18 percent more coal. The synfuels policy requires slightly less wood than the reference case, and no change in the level of uranium usage for electricity generation.

Thus, the conservation case results in a near halting of growth in primary energy consumption after 1990, whereas continuation of both the current policy and the synfuels policy result in continued growth in the consumption of primary resources. In addition, the conservation policy is the most effective in eliminating our dependence on foreign energy sources by being the only policy examined which reduces import requirements to zero by 2000 .

2.2.4 Energy System Efficiencies. The energy system developments under the three policy alternatives are summarized by the quantity and efficiency data on Table 14. All three policies result in a continuing deterioration in the average supply efficiency (total delivered energy/ total primary energy). The least deterioration in this efficiency measure results from the continuation of current policies and the greatest from the synfuels policy.

However, the efficiency with which energy service demands are met by delivered energy, the demand efficiency, improves over time in all the projections. The synfuels policy has the least impact on end-use device efficiencies with only a 27 percent improvement in the demand efficiency over the period 1980-2000. The reference case results in a slightly greater improvement (29 percent over the same period). In contrast to these two policies, the conservation policy is aimed directly at improving the energy efficiency of end-use devices through either capital stock turnover or retrofit incentives. Thus, this demand reduction policy results in almost a 70 percent improvement in the demand efficiency over the remainder of the century.

The average system efficiency reflects the changes in both the supply and demand efficiencies. It is the ratio of total energy services and total primary energy. The overall effect of the deterioration in the supply efficiency and improvement in the demand efficiency over time and in all projections resulte in a consistent increase in the average system 
Table 14

Aggregate Energy Quantities and System Efficiencies, Comparison of Cases

\begin{tabular}{|c|c|c|c|c|}
\hline & & $\begin{array}{c}\text { Reference } \\
\text { case }\end{array}$ & $\begin{array}{c}\text { Conservation } \\
\text { case }\end{array}$ & $\begin{array}{c}\text { Synfuels } \\
\text { case }\end{array}$ \\
\hline $\begin{array}{r}E_{I} \\
I \\
I I I\end{array}$ & $\begin{array}{l}\text { rgy quantities (quads) } \\
\text { Total primary energy } \\
\text { Total delivered energy } \\
\text { Total energy services }\end{array}$ & $\begin{array}{l}82.0 \\
59.4 \\
32.9\end{array}$ & $\begin{array}{l}82.0 \\
59.4 \\
32.9\end{array}$ & $\begin{array}{l}82.0 \\
59.4 \\
32.9\end{array}$ \\
\hline $\begin{array}{r}\mathrm{A} \\
\mathrm{II} / \mathrm{I} \\
\mathrm{III} / \mathrm{II} \\
\mathrm{III} / \mathrm{I}\end{array}$ & $\begin{array}{l}\text { regate efficiencies } \\
\text { Average supply efficiency } \\
\text { Average demand efficiency } \\
\text { Average system efficiency }\end{array}$ & $\begin{array}{l}.73 \\
.55 \\
.40\end{array}$ & $\begin{array}{l}.73 \\
.55 \\
.40\end{array}$ & $\begin{array}{l}.73 \\
.55 \\
.40\end{array}$ \\
\hline $\begin{array}{r}\text { Er } \\
I I \\
\text { II }\end{array}$ & $\begin{array}{l}\text { rgy quantities (quads) } \\
\text { Total primary energy } \\
\text { Total delivered energy } \\
\text { Total energy services }\end{array}$ & $\begin{array}{l}96.9 \\
68.1 \\
43.4\end{array}$ & $\begin{array}{l}86.6 \\
60.9 \\
43.4\end{array}$ & $\begin{array}{l}98.9 \\
68.3 \\
43.3\end{array}$ \\
\hline $\begin{array}{r}\mathrm{A} \varepsilon \\
\mathrm{II} / \mathrm{I} \\
\mathrm{III} / \mathrm{II} \\
\mathrm{III} / \mathrm{I}\end{array}$ & $\begin{array}{l}\text { regate efficiencies } \\
\text { Average supply efficiency } \\
\text { Average demand efficiency } \\
\text { Average system efficiency }\end{array}$ & $\begin{array}{l}.70 \\
.64 \\
.45\end{array}$ & $\begin{array}{l}.70 \\
.71 \\
.50\end{array}$ & $\begin{array}{l}.69 \\
.63 \\
.44\end{array}$ \\
\hline $\begin{array}{r}E_{I} \\
I \\
I I \\
I I I\end{array}$ & $\begin{array}{l}\text { rgy quantities (quads) } \\
\text { Total primary energy } \\
\text { Total delivered energy } \\
\text { Total energy services }\end{array}$ & $\begin{array}{r}109.4 \\
75.9 \\
54.0\end{array}$ & $\begin{array}{l}87.1 \\
58.8 \\
54.4\end{array}$ & $\begin{array}{r}113.6 \\
76.1 \\
53.2\end{array}$ \\
\hline $\begin{array}{r}\text { A } \\
\mathrm{II} / \mathrm{I} \\
\mathrm{III} / \mathrm{II} \\
\mathrm{III} / \mathrm{I}\end{array}$ & $\begin{array}{l}\text { regate efficiencles } \\
\text { Average supply efficiency } \\
\text { Average demand efficiency } \\
\text { Average system efficiency }\end{array}$ & $\begin{array}{l}.69 \\
.71 \\
.49\end{array}$ & $\begin{array}{l}.68 \\
.93 \\
.62\end{array}$ & $\begin{array}{l}.67 \\
.70 \\
.47\end{array}$ \\
\hline
\end{tabular}

efficiency: The synfuels policy results in an 18 percent improvement, the reference policy a 22 percent improvement, and the conservation policy in a 55 percent improvement in the average system efficiency over the period 1980 to 2000. Thus, while all the polfcies considered have a positive effect on the efficlency of the energy system and our use of primary energy, the conservation policy has the most significant effect, yielding more than twice the improveluent of cither the continuation of current pollcy or the jynfusls policy. 


\subsection{Environmental Implications}

Some aggregate indicators of energy-system-related environmental effects are presented in Table 15 for the three policies. Without information on the location of either the emitters or the population (both virtually impossible to assess with any degree of confidence over the relevant time span), little can be implied about the actual environmental and health effects. However, emission-creating activity and population are correlated so that the assumption that health and other effects are greater if emissions are greater is not wholly unreasonable. In addition, since these are aggregate indicators of the environmental effects, they should be used solely for comparison to the reference case and not as direct estimates of the effects generated by the policies. The conservation policy results in consistently lower measures of these effects than the reference or synfuels projections. The direction and magnitude of the changes in these indicators across the cases is largely governed by the usage of coal and uranium in each case. The synfuels case has the highest use of these resources and the highest environmental measures.

Table 15

Environmental Measures, Comparison of Cases

\begin{tabular}{lrrr}
\hline & $\begin{array}{c}\text { Reference } \\
\text { case }\end{array}$ & $\begin{array}{c}\text { Conservation } \\
\text { case }\end{array}$ & $\begin{array}{r}\text { Synfuels } \\
\text { case }\end{array}$ \\
\hline 1990 Airborne emissions, $10^{6}$ tons & 34.5 & 33.3 & 38.1 \\
Waterborne emissions $10^{6}$ tons & 1.9 & 1.6 & 2.0 \\
Person-days lost, 10 person-days & 667.0 & 607.0 & 725.5 \\
Population exposure, 106 man-rem & 0.7 & 0.5 & 0.7 \\
Coal and uranium use, quads & 39.0 & 35.2 & 42.9 \\
2000 Airborne emissions, $10^{6}$ tons & 39.5 & 32.7 & 46.6 \\
Waterborne emissions, 106 tons & 2.3 & 1.8 & 2.7 \\
Person-days lost, 10 3 person-days & 903.8 & 668.6 & 1122.7 \\
Population exposure, 106 man-rem & 0.9 & 0.6 & 0.9 \\
Coal and uranium use, quads & 53.7 & 41.8 & 61.3 \\
\hline
\end{tabular}

The airborne emissions (particulates, nitrogen oxide, sulfer dioxide, hydrocarbons, etc.) are largely created by the burning of coal for electrical and direct process heat generation, as well as the conversion of coal to synfuels. It is this differential use of coal across the policies that causes the variations in airbornc emissiums. The other fuels and technologies which contribute to these emissions are elther relatively small in magnitude (wood, oll and gas electric generation) or relatively constant across policies (oil and methanol use for transportation) and their emissions are outweighted by the difference in coal use across the policies. 
The waterborne emissions (phosphates, nitrates, suspended solids, BOD, COD, etc.) are primarily functions of coal conversion and mining. However, the effluents are contributed to by the synthetic fuel conversion process and this, in addition to the level of coal mining is responsible for the varying levels of waterborne emissions across the cases. It should be noted here that no constraints on water use or avallability were placed on the synfuels, shale o1l, and unconventional gas technologies. If the water use of these technologies were included in the analysis, then the environmental indicators for the synfuels policy would be even more significant.

The measures of health effects are of two types. The first, persondays lost, reflects the injuries and deaths caused by a specific set of technologies. Again, the shifts in coal production and the inherent health impacts of mining technology on miners outweigh any other health 1mpacts across the policles. Thus, the synfuels rase imposes the greatest health effects, while the conservation policy imposes the least, in terms of person-days lost. The second measure of health effects indicates the population exposure to nuclear related radiation (measured in man-rem). This measure is directly related to nuclear electric generation, and thus the conservation policy (with less nuclear capacity than the other policies) results in the lowest measured health effects from nuclear radiation.

\section{THE INFLUENCE OF ENERGY POLICY REPRESENTATIONS ON ECONOMIC PERFORMANCE: A SENSITIVITY ANALYSIS}

The measured economic impacts from the synfuels and conservation policies are conditional on the specific policy representations introduced into the reference projection. The importance of this dependence is bidirectional. First, for policies of this scale, the interdependencles of the energy, economic, and environmental systems are such that factuis affccting one system lead to reclprocacling interactions amnng all systems. Second, variations in the economic eflects asooclated with alternative pollcy representations and their repercussions alter the comparative advantages of pollcies with respect to their success in attaining national energy, economic, and environmental objectives. Thus, it is iupuilant to examine the sensitivity of the impacts on economic performance to variations in the policy representations.

The macroeconumic results in the subsequent assessments are determined from the application of only the DJA economic model to alteriative policy specifications: In performing these analyses, energy-economy interactinna were nnt considered. The results are indicative of only the direction of change (partial equilibrluu) rather than thr absolute magnitude of change (general equilibrium), since the fully integrated BNL/DJA model system was not employed. The information determined in this manner is sufficient for approximating the sensitivity of the economic effects to policy variations. But, for the design and evaluation of energy policy, the completeness of detail (energy, economy, and cnvironmental) afforded by the integrated BNL/DJA methodology is necessary. 
The economic effects of conservation depend on the timing of conservation expenditures, the pattern of energy savings by fuel type, and the effectiveness of conservation policy. The first of these refers to the annualization schemes applied to the cost information from the CSA program documentation. The annualized policy costs for conservation were developed from the total discounted public and private expenditures associated with each subprogram. This process involved three steps. First, the undiscounted conservation expenditures were determined for each subprogram in each of the years, 1981-2000. These then were allocated between investment goods purchases and labor services expenditures. Finally, the stream of annual investment purchases was converted into a capital services series to reflect the permanency of services available from undepreciated capital. The annual expenditures for capital and labor services constitute the direct policy costs of energy conservation. These claims are measured against the release of those productive inputs that formerly were required for energy production. For the conservation analysis just presented, resource claims exceeded releases through the early nineties, whereas the converse was true thereafter. The effects of this were to lower and raise the levels of real economic activity (relative to the reference case) in the years 1990 and 2000, respectively.

The step most critical to the above determination is the annualization of the total discounted cost information. Given the nature of discounting, a greater concentration of annual expenditures in the earlier years implies a smaller cumulative cost, 1.e., the sum of the annual, undiscounted costs over the life of the policy. Conversely, the cumulative policy cost of conservation increases the more the annual costs are deferred into the future. There are additional implications associated with the timing of the energy savings. If annual expenditures are concentrated in the nearer term, then the direct policy costs substantially exceed the direct benefits, i.e., the valuation of energy savings, in those years. However, in later periods, this situation is reversed because of lower cumulative and annual policy costs. If the annual expenditures are deferred, then there is relatively more congruence between the incidence of cost and the realization of benefits. There even exists the possibility of positive net direct benefits in the earlier years, though this is at the expense of potentially significant net costs in the future. Thus, with no modifications to either the discounted policy costs or the energy savings, changes in the time pattern and, hence, the magnitude of conservation expenditures affect whether the policy imposes a net economic cost or leads to a net economic benefit. These variations also affect the time horizon over which net costs are incurred or net benefits are realized. That is, they affect the timing of benefits and costs as measured by increases and decreases from the reference case leve1s of real GNP in 1990 and 2000 . 
For each subprogram, one of three distributional rules or patterns was selected to annualize the total expenditure data: the uniform, the constant rate of growth, and the trapezoldal. Of. these, only the last two are important to the sensitivity analyses. The programs to which the uniform distribution was applied have virtually no private sector content. Consequently, a reliable time pattern of expenditure is provided in the CSA program materials.

The pattern characterizing the constant rate of growth subprograms is one in which expenditures grow approximately in proportion to energy savings. In applying this rule, an allowance is made for unit cost reductions from increased market penetrations and economies of scale in consumption. Table 16 shows the effects on the total resource claims of doubling and halving the expenditure growth rates for these conservation subprograms. A doubling of the growth rates implies that the unit costs of energy from these conservation activities rise over time. Thus, total annual conservation expenditures are moved forward in time and increased, with the result that the levels of real GNP would be higher in 1990 and lower in 2000 than those obtained for the original specification. It is possible that, at reasonable social discount rates, pollcy variations of this type may lead to net economic benefits when compared to the reference projection. A halving of the growth rates has the opposite effect. Here, annual conservation expenditures are lowered and biased toward the nearer term, thereby further lowering real GNP in 1990 and raising it in 2000. The effect of this type of policy variation could be to exacerbate the net economic cost originally observed.

The trapezoidal distribution is selected for subprograms that initially require increasing RD\&D expenditures which level of $f$ for some

\section{Table 16}

Effects on Total Annual Policy Costs

of Varying the Expenditure Growth Rates

fonr the Constant Rate of Growth Subprograms:

Conservation Policy

\begin{tabular}{|c|c|c|c|}
\hline Case number & Policy variation & $\begin{array}{l}\text { Total resource } \\
\text { (billions of } 1972 \\
1990\end{array}$ & $\begin{array}{l}\text { claims } \\
\text { dollars) } \\
2000\end{array}$ \\
\hline II & $\begin{array}{l}\text { Original specification } \\
\text { Double growth rates } \\
\text { Halve growth rates }\end{array}$ & $\begin{array}{l}14 . ? \\
12.7 \\
14.7\end{array}$ & $\begin{array}{l}24.2 \\
40.6 \\
16.6\end{array}$ \\
\hline
\end{tabular}

length of time as the product or service provided by the program increases its penetration or effectiveness, or nears commercialization. These intervals are followed by a perlod of decreasing unit costs resulting from productivity advances in the provision of energy services from 
conservation. This distribution mechanism is applicable to subprograms for which the most likely expenditure pattern is concentrated toward the earlier years.

There are several parameters for the trapezoidal distributions that can be varied to affect the time pattern and levels of conservation outlays. These include the lengths of the growth, uniform, and decline intervals and the rates of expenditure growth and decline occurring in the first and last of these periods.

Table 17 shows the impacts on the total annual conservation expenditures that result from varying the lengths of the periods. In the first of these variants, the growth and decline periods were shortened and lengthened, respectively, with the effect of spreading a reduced level of total expenditures more evenly over time. As the total annual policy costs for 1990 and 2000 are lower than those for the original specification, the resultant levels of GNP would be higher. For the second of these cases, the period of Increasing expenditures was lengthened at the expense of the uniform period. This enlarges the original level and fraction of total conservation expenditures that occur over the decline period and, so, leads to higher unit costs in the future. Expenditures are, therefore, higher in both 1990 and 2000 and these increased annual claims would serve to increase the net economic costs of conservation policy. In the final variation of this type, the growth period was lengthened and the decline period was shortened. This has the same impact as in the prevtous case, though to lesser and greater degrees in 1990 and 2000 , respectively.

In Table 18, the effects of changes in the growth and decline parameters of the trapezoidal distributions are illustrated. Here four cases

Table 17

Effects on Total Annual Policy Costs

of Varying the Time Intervals for

the Trapezoidal Subprograms:

Conservation Policy

\begin{tabular}{ccc}
\hline Policy variation & $\begin{array}{c}\text { Total resource claims } \\
\text { (bilinns of } 1972 \text { dollars) } \\
1990\end{array}$ & 2000 \\
\hline $\begin{array}{c}\text { Original specification } \\
\text { Shorten growth period, } \\
\text { lengthen decline period } \\
\text { Shorten uniform period, } \\
\text { lengthen growth period } \\
\begin{array}{c}\text { Shorten decline period, } \\
\text { lengthen growth period }\end{array}\end{array}$ & 14.2 & 24.2 \\
\hline
\end{tabular}




\section{Tabie 18}

Effects on Total Annual Policy Costs

of Varying the Expenditure Growth and

Decline Rates for the Trapezoidal Subprograms:

Conservation Policy

\begin{tabular}{lcc}
\hline Policy variation & $\begin{array}{c}\text { Total resource claims } \\
\text { (bilions of } 1972 \text { dollars) } \\
1990\end{array}$ & 2000 \\
\hline $\begin{array}{l}\text { Original specification } \\
\text { Double growth and decline rates }\end{array}$ & 14.2 & 24.2 \\
Halve growth and decline rates \\
$\begin{array}{c}\text { Double growth rates, } \\
\text { halve decline rates }\end{array}$ & 15.8 & 22.4 \\
Halve growth rates, \\
double decline rates
\end{tabular}

are considered: doubling the growth and decline rates; halving the growth and decline rates; doubling the growth rates and halving the decline rates; halving the growth rates and doubling the decline rates. Doubling or halving both the growth and decline rates has the effect of biasing the expenditures toward the nearer or longer term, respectively. In addition, the respective cumulative costs for these policy cases are smaller and larger. Compared to the original analysis, the doubling case could increase the macroeconomic cost of conservation, whereas the reverse could be true in the case of halving the rates. Doubling the growth rates and halving the decline rates moves more of the increased total expenditures into the future with the effect of increasing the claims of conservation in 1990 and 2000. In this instance, real GNP would be lower than originally determined and the net economic cost of the policy would be higher. Finaliy, halving llie growth rate and doubling the decline rate has precisely the opposice effect.

However, for the trapezoidal distributions, it is combinations of these variations that are of interest. In comparing the cost implications of the possible combinations of cases, three variations are identified as capable of providing relatively larger deviations from the pattern of economic growth in the original cuuservation projectlun. Two nf these variations are extreme points in that they produce the largest changes in the original policy costs for both 1990 and 2000. Other combinations of interest are those for which the policy variation exerts a strong influente on the cost in one period without producing of fetting effects in the other period. Of these, only one provides more extreme policy cost effects in any period than those for the other two specifications. The annual policy cost information for these three variations is summarized in Table 19. For the first and last of these cases, the net economic cost of conservation would be lower and higher, respectively, than that for the original projection. In the instance of the second policy variation, the adverse macroeconomic impact would be larger as the 


\begin{tabular}{|c|c|c|c|}
\hline \multirow[b]{2}{*}{$\begin{array}{c}\text { Case } \\
\text { Number }\end{array}$} & \multicolumn{2}{|c|}{$\begin{array}{c}\text { Table } 19 \\
\text { Effects on Total Annual Policy Costs } \\
\text { of Combined Variations } \\
\text { for the Trapezoidal Subprograms: } \\
\text { Conservation Policy }\end{array}$} & \multirow[b]{2}{*}{$\begin{array}{l}\text { claims } \\
\text { dollars) } \\
2000\end{array}$} \\
\hline & Policy variation & $\begin{array}{l}\text { Total resource } \\
\text { (billions of } 1972 \\
1990\end{array}$ & \\
\hline $\operatorname{III}$ & $\begin{array}{l}\text { Original specification } \\
\text { Halve growth rate, } \\
\text { double decline rate, } \\
\text { shorten growth period, } \\
\text { lengthen decline period }\end{array}$ & 14.2 & 24.2 \\
\hline IV & $\begin{array}{l}\text { Double growth and } \\
\text { decline rates, } \\
\text { shorten uniform period, } \\
\text { lengthen growth perio }\end{array}$ & 20.1 & 24.1 \\
\hline $\mathrm{V}$ & $\begin{array}{l}\text { Double growth rate, } \\
\text { halve decline rate, } \\
\text { shorten decline period, } \\
\text { lengthen growth period }\end{array}$ & 16.8 & 30.8 \\
\hline
\end{tabular}

annual policy cost for 1990 is significantly higher and that for 2000 is virtually unchanged. It is interesting to note that, for the year 2000, none of these variations lead to more significant changes in policy costs than do the parametric modifications to the constant rate of growth subprograms.

The previous assessments established the sensitivity of the total annual costs of conservation policy to sequentlal changes in the annualization parameters of the constant rate of growth and trapezoidal distributions. In addition, indications were given as to the directional influence of these isolated changes on economic performance. As the logical final step of this analysis, therefore, it is important again to combine policy cases and to examine more explictly the economic effects associated with theoc reconfigurations. I'able 20 shows the effects on real GNP and the total resource claims of conservation from alternative policy representations. These reflect the simultaneous introduction of changes to the parameters of both distributional schemes. It can be seen that, with no modifications to either the total discounted policy costs or the energy savings, there are wide variations in the pattern of economic growth. Equally significant are the cumulative economic effects of temporal variations in the expenditure levels and patterns. The discounted net benefits of conservation policy are presented in Table 2.1. From this, the policy cau be seen to impose a macroeconomic cost as large as 193 billion $\$(1972)$ or lead to an overall net economic benefit of 114 billion $\$(1972)$. Again, these are conditional only on variations in the timing and annual levels of the policy costs. 


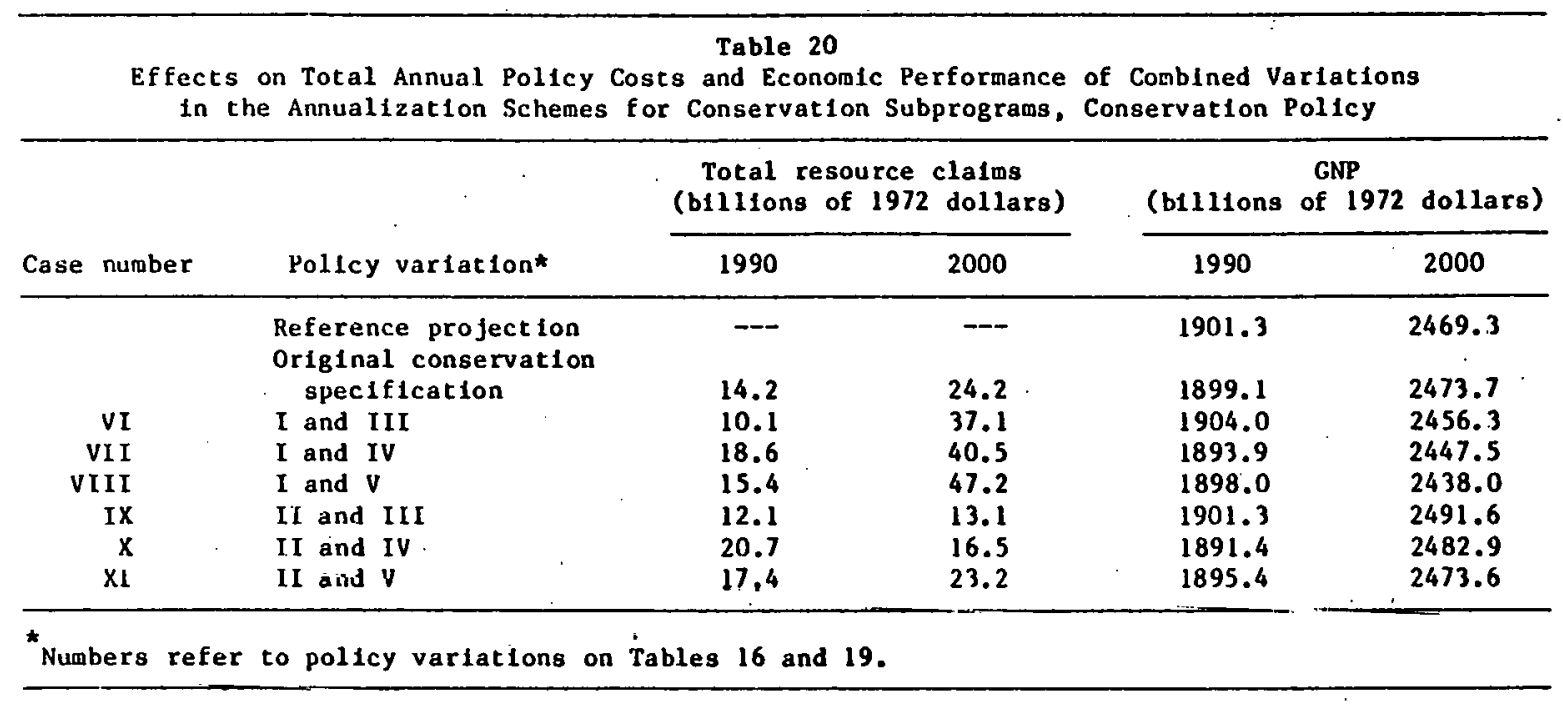

Table 21

The Discounted Net Benefits of Conservation Policy* (Billions of 1972 Dollars)

\begin{tabular}{|c|c|c|c|}
\hline \multirow[b]{2}{*}{ Case number** } & \multicolumn{3}{|c|}{ Social disrount rate } \\
\hline & $0 \%$ & $5 \%$ & $\therefore 10 \%$ \\
\hline \multicolumn{4}{|c|}{ original conservation } \\
\hline specification & 0.4 & -3.7 & $-4 \cdot 3$ \\
\hline VI & -39.3 & -12.4 & -2.5 \\
\hline VII & -185.2 & -93.8 & -51.7 \\
\hline VIII & $=192.8$ & -89.9 & -45.2 \\
\hline IX & 113.5 & 49.5 & 22.7 \\
\hline $\mathrm{X}$ & -30.1 & -30.6 & -25.6 \\
\hline $\mathrm{XI}$ & -37.2 & -26.6 & -19.1 \\
\hline \multicolumn{4}{|c|}{$\begin{array}{l}\text { * Determined as changes } I_{11} \text { the prcoent value of real GNP measured from } \\
\text { the refercnce projection. } \\
\text { ** Numbers refer to policy variations on Table } 20 \text {. }\end{array}$} \\
\hline
\end{tabular}


The purpose of the preceding analysis was to Investigate the sensitivity of the economic consequences of conservation policy to the assumptions that most influence the representation of that policy. Variations in the annualization parameters for the conservation subprograms affected the timing and annual levels of conservation outlays and the cumulative policy cost incurred over the entire projection horizon. These changes, in turn, were seen to have a significant impact on the pattern of economic growth and, hence, on the relative economic merits of the conservation strategy. However, even the case least advantageous to conservation is significantly less damaging to the economy in view of the 410-billion $\$(1972)$ cumulative net cost determined for the synfuels policy.

The second major area of sensitivity for the conservation policy concerns the division of energy savings among petroleum, natural gas, and electricity. Variations in the pattern of these savings can affect significantly the timing and magnitude of net benefits or costs. In terms of their real input claims on the economy, electricity, petroleum, and natural gas are the most, next most, and least expensive, respectively. Consequently, the more electricity that is displaced through conservation, the larger (smaller) are the net economic benefits (costs) from conservation polfcy. To illustrate this, three alternatives to the original conservation projection were specified. The total amount of primary energy savings is the same for all cases. Further, the displacement of petroleum and, hence, the value of this displacement are the same for the three alternatives. They are distinguished by the allocation of nonpetroleum savings to crude natural gas and electricity inputs. These differences lead to differences in the total quantity and mix of the delivered energy that is conserved. More important, the configuratons are different with respect to the total value and input composition of the resources released from energy production. In the first of these cases, the nonpetroleum energy savings are biased toward the conservation of inputs to electricity. In the second case, the nonpetroleum primary energy savings are divided equally between natural gas and electricity. In the third alternative, the gas-electricity split of the first case was reversed so that most of the conservation was allocated to the savings of utility gas. The macroeconomic impacts and net policy benefits for these alternatives are shown in Table 22. The policy implication of these results is clear. In designing conservation policies that promote joint1y national energy, economic, and environmental objectives, the net eronomic benefits are greatest (or, the costs are least) for strategies that place relative emphasis on substitutions away from petroleum and electricity.

Finally, for conservation, there is the issue of policy effectiveness. The controllable instrument for this policy is represented by the government outlays assoclated with each conservation subprogram. The desired effect of the public expenditure and programs is to motivate the private bector to redirect its purchases toward conservation activities. This ultimately provides the energy savings and, hence, the direct and indirect economic benefits (or, costs) from conservation policy. However, the levels of private expenditure and the resultant energy savings 
Table 22

Impacts on Economic Performance and Benefits of Varying the Hix of Energy Savings from Conservation, Conservation Policy

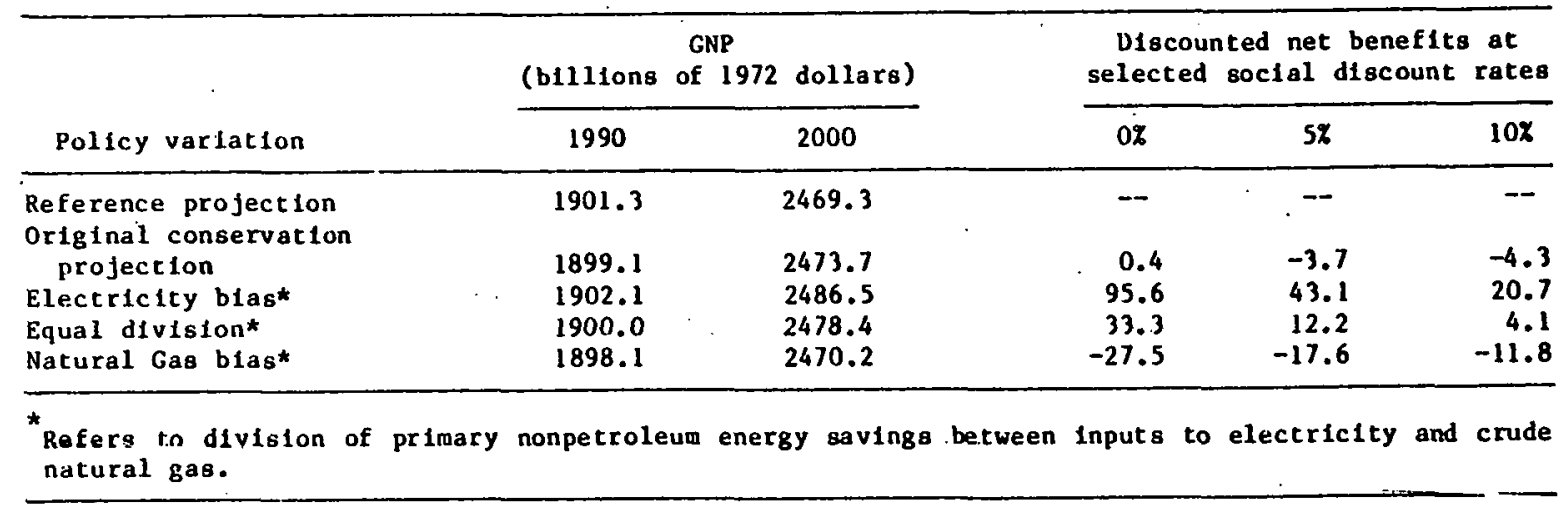

that are realized from the government incentives are the outputs of the policy. As such, they are, to some extent, uncontrollable. For the given levels of public and private expenditure, the energy savings could be significantly less than anticipated; conversely, the anticipated energy savings might be attained only at a substantially higher cost. To examine the economic consequences of these, two cases are considered. In the first, the energy savings achieved for the given levels of total expenditure were taken to be half those obtalned in the original assessment. The $\mathrm{mix}$ of these savings, however, was unaffected. For the second case, the original levels and inix of energy savings were presumed to be attained at double the original cost. Both of these cases have the effect of increasing by twofold the unit cost of energy from conservation. But, their economic impacts will differ as each case implies a different structural mix and level of resource claims and releases die to conservation policy. The effects on real GNP and the discounted net henefits of these variations are presented in Table 23. Doubling the policy cost has approximately twice the impact as does halving the energy savings. As indicated, this difference is attributable to the level and compositional implications of these changes. More important, however, is the comparison of the effects of these variations to the results for the synfuels policy. For the net economic costs of the two policies to be equal, either a doubling of the unit cost of energy from conservation or the virtual elimination of any energy savings is required for the given level of effort.

However, this issue of effectiveness also extends to the synfucls policy. In developing the synfuels projection, the input requirements for each technology were time invariant. No consideration was given to cost reductions due to learning effects, technical improvements, economies of scale, or other types of productivity advance. Changes in the costs of fuels from the synthetic and unconventional sources can affect 


\begin{tabular}{|c|c|c|c|c|c|}
\hline \multicolumn{6}{|c|}{$\begin{array}{c}\text { Table } 23 \\
\text { Impacts on Ecunomic Performance and Benefits of Varying } \\
\text { the Effectiveness of the Conservation Pollcy } \\
\text { (Billions of } 1972 \text { Dollars) }\end{array}$} \\
\hline \multirow[b]{2}{*}{ Polfcy variation } & \multicolumn{2}{|c|}{ GNP } & \multicolumn{3}{|c|}{$\begin{array}{l}\text { D1scounted net benefits at } \\
\text { selected soctal discount rates }\end{array}$} \\
\hline & 1990 & 2000 & $0 \chi$ & $5 \%$ & $10 \pi$ \\
\hline $\begin{array}{l}\text { Reference projection } \\
\text { Original conservation }\end{array}$ & 1901.3 & 2469.3 & -- & - & -- \\
\hline $\begin{array}{l}\text { projection } \\
\text { Double policy costs }\end{array}$ & $\begin{array}{l}1899.1 \\
1881.9\end{array}$ & $\begin{array}{l}2473.7 \\
2431.4\end{array}$ & $\begin{array}{r}0.4 \\
-387.5 \\
-196.4\end{array}$ & $\begin{array}{r}-3.7 \\
-203.2 \\
-103.5\end{array}$ & $\begin{array}{r}-4.3 \\
-116.0 \\
-59.3\end{array}$ \\
\hline
\end{tabular}

significantly the net economic cost associated with this policy. Three variations are considered: a doubling of the synfuels costs, a halving of these costs, and the situation in which synfuels are competitive with the energy from conservation. Table 24 presents the impacts on economic performance and net policy benefits resulting from these changes. These results clearly demonstrate the benefit potential of directing the synfuel programs toward the promotion of accelerated cost reduction rather than accelerated commercial deployment. Reducing the costs of these fuels to the point at which they are competitive with the energy from conservation more than halves the adverse macroeconomic impact of the synfuels policy.

That there still is a significant economic cost, as compared to conservation, results from two considerations. First, the mix of energy displacements and its valuation are substantially different between the two policies. The synfuels policy is not directed toward the displacement of energy, in general, or electricity, in particular. Rather, its focus is the production of petroleum and gas products by means other than importation. The effect of this can be inferred from the analysis of the pattern of energy savings, by fuel type, from conservation. As little electricity is displaced, the synfuels policy imposes a net cost on the economy that is directionally the same as for conservation with a natural gas bias (Table 23). Second, and more important, there are large differences in the composition of the resource claims, i.e., policy costs, between the two policies. For the same unit cost of energy, the synfuels policy is relatively more capital and less labor intensive than the conservation policy. The process of capital formation is crucial to economic growth and, thus, factors that affect capital formation relatively more have a relatively larger impact on economic performance. Since the synfucls policy ilivolves a relatively larger diversion of capital service inputs from other productive uses, its economic consequence is larger than that for conservatiul, even chough the unit costs of energy are the same. 


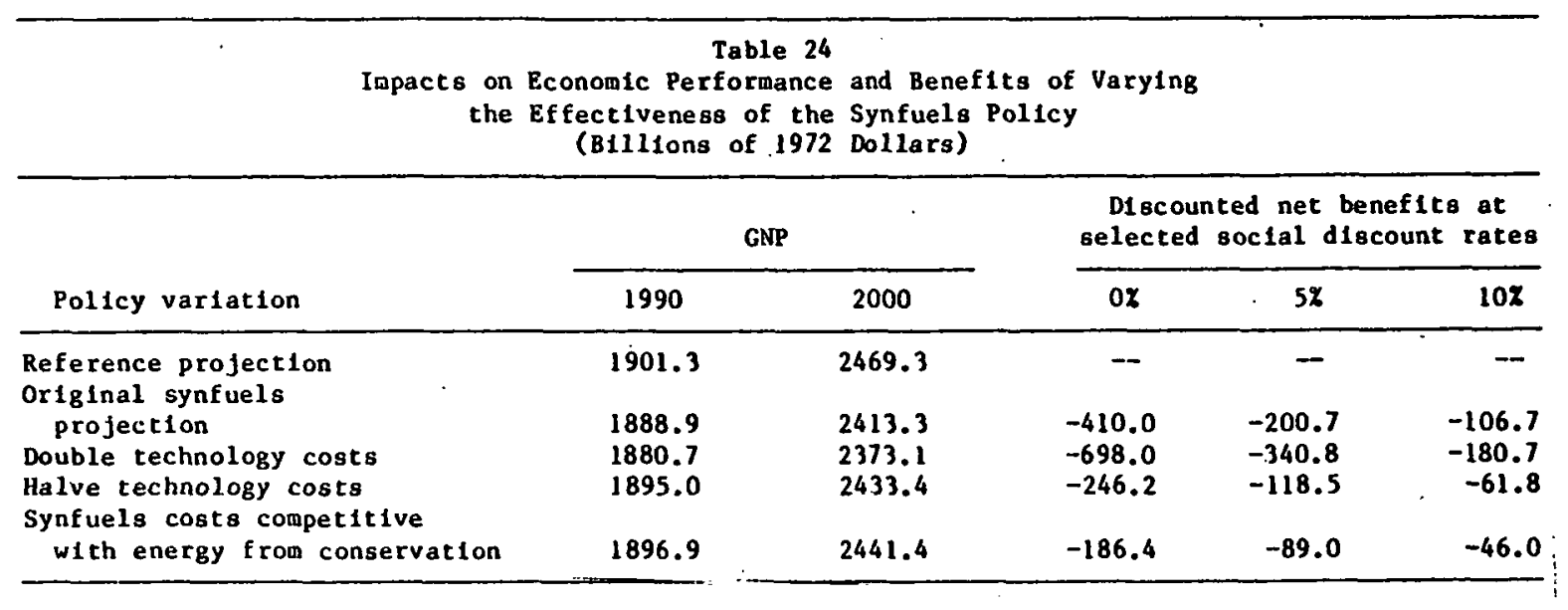

These assessments show that there are reasonable circumstances under which the comparative economic advantage of the conservation policy over the synfuels policy begins to erode. However, for the synfuels policy to be judged economically superior to conservation requires relatively extreme combinations of policy assumptions biased against demand reduction and in favor of supply expansion. Overall, there is strong analytical evidence that supports active programs for energy conservation and continued RD\&D efforts for synthetic and unconventional fuels.

\section{POLICY IMPLICATIONS}

The results from this analysis yield important implications for the focus and direction of future U.S. energy policy. Each strategy succeeds in reducing the nation's import deperidence and elowing the growth in energy demand. In the reference projection, the influences of import quotas and domestic ofl and gas price decontrol rcoult in a halving of oil imports relative to the current levels of approximately 8 million barrels per day. These influences also serve to slow the growth rate of primary energy consumption to well under 2.0 percent per annum and promote a shift in energy use patterns toward a greater utilization of coal. The introduction of the conservatlun or the aynfuels poliry further reduces U.S. Import requirements with the conservation policy being slightly more effective. Under the conservation policy, oil imports are reduced from the reference case levels by 3.5 and 8.4 quads for the years 1990 and 2000, respectively. The corresponding reducliuis for the cynfuels policy are 3.2 and 7.0 yuads. Eicher of these policies permit the almost total elimination of imports by the year 2000. From conservation, there is the additional benefit that the growth in aggregate primary energy demand is virtually halted. For the years 1990 and 2000, total primary energy savings from conservation are 10.3 and 22.3 quads, 
respectively. However, even the large-scale introduction of synthetic fuels results in only marginally higher primary energy consumption than in the reference case, being only 2.0 and 4.2 quads higher in the respective years. Thus, to different degrees, energy conservation is evident under all three of the strategies.

It is in the environmental and economic areas that the strategies most differ. For the environment, an ordering of the strategies indicates that substantial environmental benefits are obtainable from energy conservation. In addition to the emissions reductions associated with the decreased use of petroleum and natural gas, there are significant improvements in environmental quality attributable to the slower growth of total coal consumption and nuclear inputs into electric generation. Re1ative to the reference projection, future nuclear power requirements are decreased by 30.0 to 40.0 percent because of the successes of the conservation programs. Also, by 2000 , conservation leads to a 9.1 quad reduction in annual coal use, down almost 20.0 percent from the reference case amount. The energy reductions from conservation provide important bene$\mathrm{fits}$ in the forms of less damage to land, 1mprovements in air and water quality, and increased public health and safety. However, these benefits are increasingly lost in moving to the policles that characterize the reference and synfuels projections, respectively.

For the economy, the introduction of the synfuels policy imposes a significant net economic cost. Real GNP is projected to be 1888.9 billion $\$(1972)$ and 2413.3 billion $\$(1972)$ for the years 1990 and 2000 , respectively. The growth in real GNP is lower for this case than for either the reference or the conservation projections. Relative to the former, the synfuels policy results in a cumulative macroeconomic cost between 410.0 billion $\$(1972)$ and 107.0 , depending on the choice of discount rate.

The conservation results are mixed. Relative to the reference projection, the conservation policy leads to lower [1899.1 billion $\$(1972)$ versus 1901.3] and higher [2473.7 billion $\$(1972)$ versus 2469.3] levels of economic activity in the years 1990 and 2000, respectively. When discounting these annual real GNP differences, the conservation policy provides cumulative net economic benefits only at extremely low social rates of discount, e.g., 0.4 billion $\$(1972)$ at a zero discount rate. At more reasonable discount rates, e.g., 5.0 or 10.0 percent, conservation results in a cumulative net economic cost of less than 5.0 bilition $\$(1972)$.

From these comparisons, it is clear that conservation, even in isolation from other policies, can play a major role in alleviating the 1iquids problem and slowing the growth of energy demand. These goals are achieved at only a small macroeconomic cost and with substantial environmental benefits. Further, conservation compares favorably to the synfuels policy. It is slightly more successful in reducing imports and provides the only mechanism for reducing demand growth. Relative to the reference projection, there are environmental costs from the synfuels policy, whereas, with conservation, the environmental quality significantly improves. Finally, the relative impacts on economic performance are much less severe from conservation policy than from the synfuels program. 
These conclusions do not deny a potential benefit from current synfuels policies. Nor should they be interpreted as advocating a de- escalation of supply expansion programs. The favorable economic results for conservation policy as compared to synfuels are directly attributable to the policy costs of each program. In terms of only the program costs, the conservation policy provides energy at a lower cost than that of the fuels it displaces. The converse is true for the synfuels policy. For example, the 1990 cost of energy from conservation is $\$(1978) 2.10$ per million Btu while the cost of energy from synfuels is $\$(1978) 5.25$ per million Btu. Th1s suggests that synfuels programs directed toward cost reduction and the resolution of environmental issues are more appropriate than those that promote the accelerated commercial deployment of current technologies.

The measured impacts on economic performance that were determined for the policy cases are sensitive to, inter alla, the actual policy representations introduced into the reference projection. The economic effects of conservation depend on the timing of conservation expenditures, the pattern of energy savings by fuel type, and the effectiveness of conservation policy.

The first of these refers to the annualization schemes applied to the cost information from the CSA program documentation. Changes in the time pattern and, hence, the cumulative and annual magnitudes of conservation expenditures affect whether the policy imposes a net economic cost or leads to a net economic benefit. These variations also affect the time horizons over which net costs are incurred or net benefits are realized, i.e., the timing of benefits and costs as measured by increases and decreases from the reference case levels of real GNP in 1990 and 2000 . However, in varrying the annualization parameters, even the case that is least advantageous to the conservation policy imposes a significantly more moderate cost on the economy than does the synfuels policy. In fact for this case, the cumulative macroeconomic cost is less than half that for the synfuels policy [193.0 billion $\$(1972)$ versus 410.0$]$.

The secund area of sensitivity for the conservation policy concerns the division of energy savings among petroleum, natural gas, and electricity. Variations in the pattern of these savings can affect the tiuing and magnitude of net economic benefits or costs. As electricity is relatively more expensive in terms of its input claims on the economy, the more electricity that is displaced through conservation, the greater the net economic benefits from conservation policy. Cumulative economic benefits were determined to be as high as 96.0 billion $\$(1972)$ when the nonpetroleum energy savings were directed toward the conservation of electricity inputs. Alternatively, an economic cost of 28.0 billion $\$(1972)$ was observed when natural gas dominated the nonpetroleum energy savings. Thus, in designiug ennservation policies that promote jointly national energy, economic, and environmental objectives, the net economic benufits are greatest (or, the costs are least) from strategles that place relative emphasis on substitutions away from petroleum and electricity. 
Finally, there is the issue of the effectiveness of conservation policy. The controllable instrument for conservation policy is represented by the programmed expenditure of public funds. The public expenditures and programs, in turn, motivate the private sector to redirect expenditure patterns toward conservation activities. These ultimately provide the energy savings from conservation. However, the levels of private expenditure and the resultant energy savings are outputs of the policy and, to some extent, are uncontrollable. For the given expenditures, the energy savings could be significantly less than anticipated; conversely, the anticipated energy savings might be attained only at a substantially higher cost. An analysis of this suggests that only extreme increases in conservation costs or reductions in anticipated energy savings lead to a macroeconomic cost. of similar magnitude to that incurred with the synfuels program. More specifically, for the economic damages from conservation policy to equal those from the synfuels policy, either a doubling of the costs of conservation programs is required or the virtual elimination of any energy savings.

However, the issue of policy effectiveness also extends to the synfuels policy. In developing this projection, the capital and labor costs for each synfuels technology were assumed to be invariant over time. No consideration was given to cost reductions due to learning effects, technical improvement, economies of scale, or other types of productivity advance. Cost reductions for the synthetic and unconventional fuels technologies can reduce dramatically the net economic cost associated with this policy - in fact, reducing the costs of these fuels to the point at which they are competitive with the impact from the synfuels policy. In this situation, the remaining differences in the economic consequences of the two policies are attributable to the different mixes of energy displacements and structural differences in the capital and labor composition of policy costs.

Thus, there are reasonable circumstances under which the conservation and synfuels policies become less and more favorable, respectively. In these cases and in terms of macroecononic effects, the decisive comparative advantage of conservation over synfuels begins to erode. However, for synfuels to be judged economically superior to conservation requires relatively extreme combinations of policy assumptions biased against demand reduction and for supply expansion.

As the principal implication evidenced by these analytical results, active programs for energy conservation and continued RD\&D support for synthetic and unconventional fuels belong as integral components of future U.S. energy policy.

\section{REFERENCES}

1. Davitian, H., Groncki, P.J., Kleeman, P., Lukachinski, J., Goettle, R.J., and Hudson, E.A., A Strategic Cost-Benefit Analysis of Energy Policies: Overview, BNL 51105, 1979.

2. Davitian, H., Groncki, P.J. Kleeman, P., Lukachinski, J., Goettle, R.J., and Hudson, E.A., A Strategic Cost-Benefit Analysis of Energy Policies: Detalled Projections, BNL 51127, 1979. 


\section{REFERENCES (CONT.)}

3. Groncki, P.J. and Marcuse, W., The Brookhaven Integrated Energy/ Economy Modeling System and Its Uses in Conservation and Policy Analysis, BNL 51056, 1979.

4. Hudson, E.A. and Jorgenson, D.W., The Long-Term Interindustry Transactions Model: A Simulation Model for Energy and Economic Analysis, Final Report to the Applied Economics Division, Federal Preparedness Agency, General Services Administration, 1977.

5. Kydes, A.S., The Brookhaven Energy System Optimization Model: Its Variants and Uses, BNL 50873, 1978. 